\title{
PRAGUE SPRING'S DEMISE: \\ THE INVOLUNTARY EMIGRATION OF THE JOURNALIST VLADIMÍR TOSEK
}

\author{
LA DERROTA DE LA \\ PRIMAVERA DE PRAGA: \\ LA EMIGRACIÓN INVOLUNTARIA DEL PERIODISTA VLADIMIR TOSEK
}

\author{
Daniela Spenser \\ Centro de Investigaciones y Estudios Superiores \\ en Antropología Social \\ daniela.spenser@gmail.com
}

"What a terrible world it is in which you can choose between a homeland that promises suffering and the suffering that afflicts those who choose to renounce their homeland".

\begin{abstract}
The attempt to reform the authoritarian regime in Czechoslovakia was aborted by Soviet-led military invasion in August 1968. The television journalist Vladimir Tosek broadcasted the occupation until the transmission was discovered, and he was forced to cross the border to Austria. He did not want to emigrate, but the radical political change forced him to exile. The Czechoslovak authorities made him pay a heavy price for daring to defy the occupiers in 1968 by making public his previous collaboration with the state secret police. The government sought to discredit Tosek and his colleagues who defended vigorously the reform process.
\end{abstract}

Keywords: Prague Spring, 1968-1969, Vladimír Tosek, emigration.

\section{Resumen}

El intento de reformar el régimen autoritario en Checoslovaquia fue abortado por la invasión militar liderada por los soviéticos en agosto de 1968. El periodista Vladimír Tosek transmitió la ocupación hasta que fue descubierto y se vio obligado a cruzar la frontera con Austria. No quería emigrar, pero el cambio político radical, que culminó en abril de 1969, lo obligó a exiliarse. Las autoridades le hicieron pagar un alto precio por desafiar a los ocupantes en 1968 haciendo pública su anterior colaboración con la policía secreta del Estado. Al hacerlo, el gobierno buscó desacreditar a Tosek y a sus colegas.

Palabras clave: Primavera de Praga, 1968-1969, Vladimír Tosek, emigración.

1 Klíma, Ivan (2013), My Crazy Century, New York, Grove Press, p.258. Tosek was my mother's second husband; the article is based in part on his archive. 


\section{Introduction}

In this article I wish to contribute to studies of the initial stage of the so-called 'normalization,' which followed the occupation of Czechoslovakia by the Warsaw Pact troops and which spanned the period from August 1968 to April 1969. 'Normalization' sought nothing less than to normalize an anomaly: the foreign military occupation of the country, which turned the historical clock back to the Stalinist era and which the reform process of 1968, the Prague Spring, ideally tried to overcome. This initial stage, dubbed Alexander Dubček's 'normalization,' ended with his fall. ${ }^{2}$ Dubček, who symbolized the Prague Spring, was replaced in April 1969 by Gustav Husák, who was much more pliant to the Soviet leadership, and who permitted wholesale censorship to be restored in the Czechoslovak mass media. The reform movement of 1968 was over.

There is no shortage of literature and scholarly debates on the subject. ${ }^{3}$ I choose to delve into the experience of Czechoslovak journalist Vladimír Tosek during the first months of 'normalization,' gleaning through an examination of his life the ways in which this anomalous process unfolded and examining the means by which it was accom-

2 Williams, Kieran (1997), The Prague Spring and its Aftermath. Czechoslovak Politics 1968-1970, Cambridge, Cambridge University Press, pp. 144-191.

3 In addition to Williams's study, see Sviták, Ivan (1971), The Czechoslovak Experiment 1968-1969, New York and London, Colombia University Press; Tigrid, Pavel (1971), Why Dubček Fell. London, Macdonald; Kusín, Vladimir (1978), From Dubček to Charter 77: A Study of Normalization in Czechoslovakia, 1968-1978, New York, St. Martin's Press: Šimečka, Milan (1979), Obnoveni pořádku. Koln: Index; Pehe, Jiři ed. (1988), The Prague Spring: A Mixed Legacy and New York, Freedom House; Dubček, Alexander with Jiři Hochman (1993), Naděje umirá poslední. Vlastní životopis, Praha, Svoboda; Pecka, Jindřich and Vilém Prečan (1993), Proměny Pražského jara 1968-1969. Sborník studií a dokumentů o nekapitulantských postojích v československé společnosti, Brno, Doplněk; Otáhal, Milan (1995) 'K některým otázkám dějin "normalizace"', Soudobé dějiny 1, pp. 5-16; Doskočil, Zdeněk (2006), Duben 1969. Anatomie jednoho mocenského zvratu, Brno, Doplněk; Bren, Paulina (2010), The Greengrocer and his TV: The Culture of Communism after 1968 Prague Spring, Ithaca and London, Cornell University Press; Petráš, Jiři and Libor Svoboda eds. (2017), Jaro'68 a nástup normalizace. Československo v letech 1968-1971, České Budějovice and Praha, Ústav pro studium totalitních režimů. plished. The era's press and archives, and above all, Tosek's personal correspondence provided the evidence to formulate and document my arguments.

\section{Background}

Vladimír Tosek was born in Prague into a secular Jewish family in 1919 and died in London in 1987. Born a child prodigy, his well-to-do parents cultivated Vladimír's learning of languages. By 1938, he spoke several, was well-travelled and, to further his education, was sent to England in the nick of time before Czechoslovakia ceased to exist and one part was forcibly incorporated into the Third Reich. His parents, who did not accompany or follow Vladimír, were herded to their death in Auschwitz.

In England, Vladimír enrolled in the Manchester School of Commerce to study foreign trade and had several jobs in wartime Britain until 1941 when he joined the Czechoslovak army. As part of the Czechoslovak armored brigade, he fought in northern France under Allied land forces commander Montgomery. It was in England that he met some of the exiled Czechoslovak communist leaders, but he did not join the party until he returned to Prague, becoming its staunch adherent. In his application for a job in the Czechoslovak radio service in July 1945, Vladimír extolled his linguistic qualities and patriotic engagements in England.

$\mathrm{He}$ was hired by the radio monitoring service and became the head of short-wave broadcasting for the English-speaking world but during the wave of the Stalinist show trials, Vladimír, a Jew and a soldier in the western army, was sacked from his job. In the characteristic language of the time, Vladimír's secret police file stated that 'he was born into a bourgeois family, that his parents invested in him so that he perfected foreign languages and that in western countries.' Furthermore, it was known at the radio station that he was not firm enough 'to persuade the masses. ${ }^{.4}$

4 Vesely, Jar. 'Vladimír Tosek-poznatky,' Prague, November 27, 1951, Archiv Bezpečnostnich Složek (State Security Archive (hereafter ABS), file 12402-326. 
After the relative relaxation of the stringent political atmosphere in Eastern Europe following the $X X$ th Congress of the Soviet Communist Party in February 1956, Vladimír was offered a job as a journalist on Czechoslovak television. When Jiří Pelikán, a reform communist avant la lettre, became its director, he brought fresh air into the ideologically asphyxiated medium. ${ }^{5}$ It was under Pelikán's directorship that Tosek became a television star as foreign news commentator. He interviewed the Cuban revolutionary Fidel Castro and his Argentinean comrade Che Guevara; he shook hands with the American black singer Paul Robeson; from Vietnam he returned with a piece of an American aircraft shot down by the North Vietnamese soldiers; and in Italy he shot picturesque scenery to delight his audience. In sum, Vladimír brought to his viewers forbidden to travel abroad a world they could not see for themselves.

But in 1968, without doubting for a moment, Vladimír boarded the train conducted by the Slovak party leader Alexander Dubček and his close allies whose aim was to liberalize the dead-end system. As a journalist, he contributed to opening up the windows onto the country's hidden reality, forcing the rules of censorship to a breaking point and promoting freewheeling discussions about people's problems and views on a myriad of acute social, economic, political and personal issues. Then, just as the pathbreaking radio and television initiatives were getting off the ground, the Soviet-led invasion of Czechoslovakia on 21 August 211968 put an end to them.

Tosek was one of those television journalists who, in defiance of the invaders, took matters into their own hands and improvised broadcasts covering the occupation of the Warsaw Pact armies until they could no longer broadcast. After changing places from one television studio to another in Prague, he moved to a transmitter outside the capital city. When the invading troops discovered his location, he and his team travelled

5 Štoll, Martin (2019), Television and Totalitarianism in Czechoslovakia. From the First Democratic Republic to the Fall of Communism, New York, Bloomsbury, pp. 169-174. to a military transmitter in southern Bohemia. This became the last makeshift studio from which he and the technical team could convey news on the foreign occupation to local and international viewers. When they learned that Soviet tanks were approaching, the journalists abandoned that transmitter as well. On the sixth day of the occupation, on Monday 26, they crossed the frontier to Austria with the help of the Czechoslovak local border patrol. The technical team returned to Prague with their equipment soon after, while Vladimír stayed on in Vienna. His wife Ruth joined him on Thursday 29. ${ }^{6}$ They adopted a wait-and-see attitude, while at home in Prague a witch-hunt against journalists was underway.

\section{In Limbo}

Vienna in the fall of 1968 was a beehive of refugees from occupied Czechoslovakia, some of whom scurried from embassy to embassy in search of the most suitable country for emigration.

Others stayed put, waiting to see if the conundrum back at home would take a turn for the better, hoping that party and government leaders would take a firm stand vis-à-vis the occupiers; or for the worse, accepting and implementing the dictates, signed in Moscow under military duress, demanding an end to the process of reforming socialism and replacing its implementors. ${ }^{7}$

While awaiting one outcome or another, reading the news, exchanging information

6 'Vyšetřovací spis k osobě Vladimíra Toska', ABS, file V-34970; Cysařová, Jarmila (2003), 'V Československé televizi,' Jiři Pelikán 1923-1999, Prague, OPS občanský dialog, pp.45-46; Svejkovský, Jiří (2010), Čas marných nadejjí. Roky 1968 a 1969 ve zpravodajství ČST, Prague, Epocha, pp. 1774; Pulec, Martin (2013), 'Nestandardní jevy u Pohraniční stráže v posrpnovém období roku 1968,' Úrad dokumentace a vyšetřováni zločinů komunismu. Prague pp. 9-61; Štoll, Martin (2019), Television and Totalitarianism in Czechoslovakia. From the First Democratic Republic to the Fall of Communism, New York, Bloomsbury, pp. 181-182.

7 Daneš, Ladislav (2005), Múj život s múzami, televizi a tak vủbec, Praha, Malá Skála, pp. 112-114; Kosta, Jiři (2002), Život mezi úzkostí a nadějí. Praha, Paseka, pp. 132-135. When abducted to Moscow at gunpoint, Dubček and the other Prague Spring leaders were forced to sign an agreement to legitimize the invasion. 
with friends and acquaintances, Vladimír and Ruth looked for temporary jobs. Neither had difficulties with German or other languages spoken in central Europe. In no time, a network of journalists was formed and sprang into action. Vienna, London, Munich, Paris, Amsterdam, Zurich and Rome turned into hubs and labor exchanges for those who had become targets of the early normalizers. ${ }^{8}$ Ruth, a jack of all trades, found a job at United Press International in Vienna as desk editor and performed odd office duties. Vladimír obtained a temporary job in Mexico where, on behalf of the consortium Eurovision, he helped in the preparation of the 1968 Olympic games in September and their execution in October. During his six weeks in Mexico City, he was busy with planning and organizing accommodations in hotels and transportation of delegates to and fro, with no spare time to see anything of the country or savor the Czech gymnast Věra Čáslavská's bitter-sweet triumphs.

It was on October 25, 1968 that the multiple gold medalist Čáslavská stood next to the Soviet gymnast with whom she shared a gold medal in one of the disciplines. The two national flags were raised simultaneously but the Czech anthem was played first. At the sound of the Soviet anthem, Cáslavská tilted her head in repudiation of the invasion of Czechoslovakia by the Soviet Union, for which it should have been excluded from the games for behaving contrary to the humanitarian mission of the Olympic charter, ran the headlines of the local newspapers. ${ }^{9}$ A few days before, during their medal ceremony the African-American athletes Tommie Smith and John Carlos, who won gold and bronze medals respectively in the 200-meter running event, heard the American national anthem with a raised black-gloved fist. Both gestures, the

8 Jiři Pelikán, director of Czechoslovak television until the Soviets demanded his resignation, left Czechoslovakia in September, took a diplomatic position at the embassy in Rome and owing to his wide net of acquaintances among European media networks, helped whom he could.

9 For Čáslavská's performances at the Olympic Games, see the documentary film by Olga Sommerová, Věra 1968, vzlety a pády nejslavnějši české gymnastky Věry Čáslavské (2012). fight for civil rights and for freedom and national sovereignty, turned the Olympic games into an overt political statement in a country in which an authoritarian regime headed by President Gustavo Díaz Ordaz sought to showcase the nation as peaceful, stable and orderly. But a few days prior to the inauguration of the Olympic games, the president ordered the army, the police, the paramilitary and the elite presidential guards to repress a youth movement at Plaza Tlatelolco, which resulted in the assassination of an unknown number of citizens. Tosek witnessed the way Mexico's image as a relatively democratic nation was tarnished before the eyes of the entire world.

In early November, Vladimír turned up in Paris. He was anxious to find a job, which would entitle him to an extension of a legal permit to remain abroad from his employer in Prague. He kept on writing letters left, right and center to different European press and broadcasting agencies, but to no avail. Jobs that had been offered to him were just as easily cancelled. He was too well known, and agencies feared diplomatic retaliation without specifying from whom. Gloom was also overtaking him as he watched the events across the border. ${ }^{10}$

On October 28, the fiftieth anniversary of the founding of the Czechoslovak Republic following the dismemberment of the Austro-Hungarian Empire, protests erupted in most major cities; in Prague, the police tried to persuade the throng to disperse, but in the end resorted to truncheons. On November 7, the anniversary of the Bolshevik revolution, small groups in Prague pulled down Soviet flags and burned them; once again the government deployed police with truncheons, fire hoses, and reinforced them with the People's Militia. As November 17 (the International Students' Day) was approaching and with it the anniversary of the Nazi shooting and subsequent death in 1939 of the student Jan Opletal, the leaders feared what the media might do to inflame the atmosphere and bring back Soviet troops to the cities' centers. Thus, it was time to

10 VT to Viktor Rưžička, Vienna, November 20, 1968, personal archive (thereafter pa). 
crack down on journalists, accused of inspiring this organized disorder and adopt a "firm course." Dubček warned against the "rightist danger," while in the same breath he urged people not to succumb to skepticism that the new course of the party had been abandoned. Citizens should "remain optimistic but disciplined"11. However, personalities identified with the reform cause had to leave the central organs of the party as did the presidents of the Czechoslovak radio and television services ${ }^{12}$. The government adopted the formula of "temporary control of the press"13.

Vladimir watched the fight for the continuation of several journals as well as the banning of critical programs on television and radio. While Dubček tried to salvage some semblance of continuity with the reform process, his nemesis Husák condemned the continued activity of antisocialist forces, imitating Soviet-dictated language about anti-Soviet and rightist threats to the country and their infiltration into the mass media. ${ }^{14}$ The press was singled out as a threat to the regime at the time when students and factory workers publicly defended the policies of the Prague Spring and its leaders. But the leaders, like the popular Josef Smrkovský, begged workers in a television broadcast not to strike on his behalf, while Dubček was undermining what hopes there remained among people by urging caution so as not to provoke the Soviets. ${ }^{15}$

Vladimír in Vienna was nauseated by what he saw on the television screen, heard on the radio and read in the newspapers. ${ }^{16}$ To add to his dejection was the cancellation of another promise of a job at the BBC for

11 Williams, Kieran, (1997), The Prague Spring and its Aftermath. Czechoslovak politics 1968-1970, Cambridge, Cambridge University Press, pp. 174-176.

12 Dubček, Alexander and Jiři Hochman (1993), Naděje umirá posledni. Vlastni životopis, Praha: Svoboda, p. 225.

13 Dubček, Alexander and Jiři Hochman (1993), Naděje umirá poslední. Vlastní životopis, Praha, Svoboda, pp.219-233.

14 Williams, Kieran. (1997), The Prague Spring and its Aftermath. Czechoslovak politics 1968-1970. Cambridge: Cambridge University Press, pp. 175-183.

15 Kavan, Jan (1988), 'From the Prague Spring to the Long Winter,' in Pehe, Jiři ed., The Prague Spring: A Mixed Legacy, New York, Freedom House, pp. 108-113.

16 VT to Pelikán, Vienna, December 9, 1968, pa. unspecified internal and political problems. In Italy, he was told, it would be difficult to find employment because of conflicts between the Socialist and the Communist parties. The Italian Communists would not hire a Prague Spring journalist because they wanted to avoid polemics with Soviet comrades about the reform process and its demise. They also believed that Communists should return to Czechoslovakia and that if they did not, the Italian comrades should sever contacts with them, never mind help them. ${ }^{17}$

Knowing all this, the well-connected Pelikán, sheltered at the Czechoslovak embassy in Rome as a cultural attaché, was helping Vladimír overcome unending difficulties. He approached his friends at Radiotelevisione Italiana (RAI), where the obstacle might be labor Unions' resistance to hiring a foreigner. When Pelikán was writing this letter, Vladimír received a ray of hope by way of a note from Fabio Borrelli, director of foreign relations of RAl, offering him a plane ticket to go to Rome for an interview. ${ }^{18}$ Vladimír's soon to expire Austrian visa did not allow him to go to Italy at that moment in December and he had to wait until he was certain that he could return to Vienna safely.

It is noteworthy that in Pelikán's letter of December 1968, his perception was that the supporters of the military occupation in Czechoslovakia had been weakened by the firm stand taken by industrial and cultural workers; that the regime was not contemplating jailing the opposition and that there was still hope. Pelikán, wrongly as it turned out, believed that the coming détente between the superpowers could lead to a reduction of tensions in Europe, which would weaken the position of the dogmatists and the cold warriors on both sides of the ideological spectrum. ${ }^{19}$

We now know that the opposite happened: as international tension was reduced, Leonid Brezhnev, who masterminded the invasion of Czechoslovakia, and the dogma-

17 Pelikán to VT, Rome, December 13, 1968, pa.

18 Fabio Borelli to VT, Rome, December 10, 1968, pa.

19 Pelikán to VT, Rome, December 13, 1968, pa. 
tists of his ilk, felt free to act without international inspection or interference in their sphere of influence. The continuing Cold War in fact stabilized relations between the superpowers in Europe. ${ }^{20}$

\section{January}

Vladimír made the trip to Rome on January 8. Radiotelevisione Italiana offered him a one-year contract as an external collaborator, with a salary equivalent to that of an Italian journalist and with a starting date in the middle of February. The work content was not specified, but it was agreed that he would collaborate in tasks relative to television journalism and documentary production, and RAI would take advantage of his linguistic skills for its stories about international relations. It was Vladimir's decision that neither his face nor his name would ever appear in public; he was and wanted to remain a Czechoslovak journalist, with legal residence abroad, among other reasons so that his children could visit him. The collaboration with RAl would have many advantages for Czechoslovak television, he claimed, for he would learn new technical, programming and publicity skills, would be able to shoot documentaries, produce reports about Italy and, last but not least, the job would enable him to write a book with the ingenious working title 'Ukážu ti cestu RAlem-kniha o Italii, jejím rozhlase a televizi.'21 Vladimír painted an idyllic situation. However, before moving to Italy, he needed to go to Prague to settle practical matters, above all to replace his soon to expire official passport with a new one. ${ }^{22}$

Shortly before Vladimír's trip, the leadership of the Union of Czech Journalists met to acquaint themselves with the new Communist Party Central Committee's

20 Vinen, Richard (2019), The Long '68. Radical Protest and Its Enemies, London, Penguin Random House, pp. 302-303. 21 'I'll show you the road through RAI- a book about Italy, its radio and television.' Ráj in Czech is paradise.

22 VT, 'Informace o mé návštěvě v Římě a námety z ni vyplývajíci,' Vienna, January 15, 1969, pa. Next to their private passports, Vladimír, Ruth and people who travelled on business abroad were issued passports for travel on behalf of the institutions they represented. measures relative to mass media, such as restoring control over what could be aired or published, without implementing a fullscale censorship. Control over the media would be the responsibility of editors; and there would be no dismissal of journalists or repressive measures against newspapers and journals. However, by the middle of the month, Dubček talked about enforcing the principle of 'democratic centralism,' meaning accepting decisions taken by state organs, limiting debates and denouncing "petty bourgeois radicalism" and anarchistic tendencies among the youth. ${ }^{23}$ Journalists knew only too well the meaning of such menacing words; they harked back to the Stalinist past. The atmosphere in Prague was thick with rumors and turned heartrending after the student Jan Palach set himself on fire in protest against the foreign occupation and its gradual regularization on January 16 and died on January 25.

His burial turned into a mass demonstration against the invasion. Tragically, "though stunning in its dignity, this approach brought no political rewards." 24

Vladimír was aware that going to Prague was risky, but it was the only alternative he had if he wanted to legalize his stay abroad. There was a reason to be concerned. His and Ruth's exit permits were soon to expire, so he sent their private passports to Prague with the application for renewal but was notified that their permits had been denied and their passports retained by the authorities. Fortunately for both, they still had their official passports. Vladimír hoped that his

23 'Záznam o jednání predsednictva Svazu českých novinářu o některých okamžitých opatření UV KSC v oblasti hromadných sdělovacích prostrědků (1.13.1969),' typescript, pa. 24 Hochman, Jiři (1988), 'Words and Tanks: The Revival, the Struggle, the Agony and Defeat (1968-1969),' in Pehe, Jiři ed., The Prague Spring: A Mixed Legacy, New York, Freedom House, pp. 108-113; Kavan, Jan (1988), 'From the Prague Spring to a Long Winter,' in Pehe, Jiři ed., The Prague Spring: A Mixed Legacy, New York: Freedom House, pp. 109-111; Dubček, Alexander and Jiří Hochman (1993), Naděje umirá posledni. Vlastni životopis. Praha: Svoboda, pp. 236-237; Williams, Kieran (1997), The Prague Spring and its Aftermath. Czechoslovak politics 1968-1970. Cambridge: Cambridge University Press, pp. 188-190. The story of Jan Palach was dramatized by Agnieszka Holland in the film The Burning Bush (2013). 
employer would step in and arrange his legal stay abroad on behalf of Czechoslovak television. If not, "it would mean an artificial production of emigrants and moreover of people who had no such intentions." 25

Vladimír also wrote to the prime minister Oldřich Černík, who, as early as September 1968, was selected by the Soviet leaders to undermine Dubček's authority and who asked the Soviets for advice on how to deal with a group of journalists, mostly Jews he added, whom the Czechoslovak leaders wanted to send out of the country for five to ten years as cultural or trade representatives, so as to avoid having to take political steps against them and thus making them "embittered émigrés." 26 Vladimír assured the prime minister that he was and wanted to remain a Communist journalist who after a stint abroad would return home. He had not engaged in any activity contrary to the party and state leadership; he had not written a single line or made any declaration which would distance him from the reform course of $1968 .{ }^{27}$

Vladimír knew better: his personal archive testifies to his knowledge of the degree to which the Dubček leadership was retreating from the reform program of 1968 and the changes that were taking place in Czechoslovak television, removing prominent journalists from their responsibility in programming, barring others from appearing on the television screen or sacking them altogether. Reportedly, Vladimír's fate was also on the line. In the same letter to the prime minister, he expressed solidarity with his television and other colleagues in the media, ${ }^{28}$ something that could not have

\footnotetext{
25 VT to Josef Smidmajer, ústrední reditel Cs. televize, Vienna, January 31, 1969, pa.

26 Over the next few months, Černík performed the role that he was assigned to the full satisfaction of the Soviets. He was even offered Dubček's job, which he turned down in anticipation of the 'nasty measures' Dubček's successor would have to take, see Williams, Kieran (1997), The Prague Spring and its Aftermath. Czechoslovak politics 1968-1970, Cambridge: Cambridge University Press, pp. 173-209.

27 VT to Oldřich Černík, Vienna, January 31, 1969, pa.

28 Arnošt Frydrych to VT and RT, Prague, February 2, 1969 , pa; Svejkovský, Jiři (2010), Čas marných naději. Roky 1968 a 1969 ve zpravodajstvi ĆST, Prague, Epocha, p. 87; Daneš, Ladislav (2005), Můj život s múzami, televizi a tak vübec, Praha: Malá Skála, pp. 118-121; Cysařová, Jarmila (1993),
}

endeared him to someone like Černík who was bent on getting rid of them. He never received a reply.

\section{February}

Vladimír crossed the border on February 6. His arrival in Prague was preceded by a diatribe against him published in the Soviet-manufactured pamphlet called Zprávy (News.) Put out with the help of the Soviet army, a poorly edited collection of slander and calls for revenge, Zprávy accused Vladimír of having collaborated in 1968 with the British diplomat and press attaché Cyril Jonsen. Even though the details of these contacts were unknown to $j k$, the author of the smear, in August Tosek supposedIy provided Jonsen with information on party and government positions. "Vladimír Tosek is allegedly in Vienna. His partner (sic) is supposed to be working there with a Jewish organization Joint. Both of them left Czechoslovakia without a legal travel document. How they left is still insufficiently known." 29 Most likely, jk was an interior ministry hack with no scruples about resorting to lies. Vladimír, in fact, had legal documents when he crossed the border and Ruth was not working for a Jewish organization, but for the United Press Agency. Facts did not matter.

The same day that Vladimír was on the train travelling to Prague, interior minister Josef Grösser met with leading party members from around the country and informed them about anti-state groups that had sprung up. Among them was the so called 'control room for Czechoslovak journalists and cultural workers' in Vienna, led by the former employee of Czechoslovak television Tosek, most likely also participating in the broadcasts of Radio Free Europe and elaborating materials about Czechoslovakia. ${ }^{30}$ The canard probably referred to the

Česka televizni publicistika, svědectví šedesátých let. Prague: Edice Česke televize 66, p. 123

29 jk, 'Ve středu zájmů imperialistických rozveděk.' Zprávy, (February 1, 1969) 7; 'Soviet Attack on Prague Britons.' The Times, (February 4, 1969). The American Jewish Joint Distribution Committee was and is a Jewish relief organization. 30 'Ministerstvo vnitra k prípadů Vl. Toska,' Svobodné Slovo. 
informal support network helping Czechoslovak journalists to find jobs that indeed existed. The news travelled across the country as far as to eastern Slovakia and southeastern Moravia. ${ }^{31}$ What incensed Vladimír most about the newspaper report of the meeting was the reference to him as a 'former' employee of Czechoslovak television.

In Prague, the new but decent television director went out of his way to apply to the interior ministry on Vladimír's behalf to secure him a new passport and an exit permit for both him and his wife. On February 19, Vladimír was summoned for an interview at the ministry. The meeting with the officials, whose job it was to issue passports, turned into an interrogation. The questions swirled around the circumstances of his broadcast during the first days of the occupation; they wanted to know names, but most importantly they inquired about how Vladimír crossed the border on August 26, 1968, an action which his interrogators called unlawful. Their insistence on the illegality of the border crossing, Vladimír thought, was intended to disqualify the work of the Czechoslovak television team's broadcasting during the heady days following the military invasion. The border crossing was illegal, they concluded, because Vladimír could not produce the obligatory stamp on his exit permit. Then they wanted to know who he knew from his travels abroad. He replied that he knew many people but would not name names. The next thing his interrogators did was to take away his official passport. ${ }^{32}$

However, the essence of the interrogation lay elsewhere. The Prague Spring was

\footnotetext{
Prague (February 26, 1969); 'Vl. Tosek odpovídá,' Svobodné Slovo. (February 28, 1969); VT, 'Kterak jsem si šel pro vlnu a vrátil se ostřihán,' Práce, (March 1, 1969). Founded in 1949 by the U.S. government, Radio Free Europe broadcasted news to Eastern Europe to counter the Soviet-inspired news making.

31 'Vaša otázka-naša odpověd,' Východoslovenské noviny, orgán východoslovenského krajského výboru KSS. Prague (February 25, 1969): 'Aktiv funkcionárư KSC v Hodoníne, Slovácko (February 26, 1969).

32 For the criminalization of border crossing, see Rychlik, Jan (2016), 'Překračování hranic a emigrace v Československu a východní Evropě ve 20. století,' Securitas imperii, 29, pp. 1072; VT, 'Kterak jsem si šel pro vlnu a vrátil se ostřihán,' Práce, (March 1, 1969), 4.
}

a legitimate cause, interrupted by an illegitimate occupation which the current interrogators represented. A few days later, on February 24, still uncontrolled, the daily Svobodné Slovo carried a few words about Vladimír's encounter at the interior ministry, which the latter dismissed as mere questioning about his border crossing. Vladimír believed the attack on journalists like him camouflaged an assault on the leading personalities of the Prague Spring.

Indeed, reformers still holding on to their posts had been singled out for removal by the so called 'realists.' The country was in a real crisis, argued Černík, because the power of the party-state had been weakened. But make no mistakes, he admonished, any unrest would be crushed by Czechoslovak tanks in order to restore stability. ${ }^{33}$

\section{March}

After this harrowing experience, Vladimír penned a provocative newspaper article, with the title 'Kterak jsem si šel pro vlnu a vrátil se ostrihán' or 'How I went for wool and returned sheared,' which became an instant talk of the town item. ${ }^{34}$ But Zprávy was relentless and went on the attack again on March 15 against those television journalists who like Vladimír spent the war years in England and in the western army. It did not matter that the author invented the fact that Vladimír had a brother who worked for the BBC. What mattered was to hammer home the point that people like him "are in fact carrying out antisocialist and antiSoviet, that is to say counterrevolutionary politics." 35 A poignant proof for the authorities was the 'ice-hockey crisis.'

33 'Občanský postoj umělců,' Svobodné Slovo. (February 24, 1969) 4; 'Ministerstvo vnitra k prípadu VI. Toska,' Svobodné Slovo. (February 26, 1969) 3; VT, 'Moje únorové události,' Reportér, IV/8, (February 27, 1969) ,15: 'Vl. Tosek odpovida, Svobodné Slovo, (February 28, 1969), 3; Williams, Kieran (1997), The Prague Spring and its Aftermath. Czechoslovak politics 1968-1970, Cambridge, Cambridge University Press, pp. 193-194.

34 'Kterak jsem si šel pro vlnu a vrátil se ostřihán,' Práce, March 1, 1969; Šimečka, Milan (1969), 'Strategie naděje, Listy, March 13, 10.

35 Váňa, Josef (1969), 'Z televizní kuchyňe a zakulisi,' Zprávy, March 15, 4. 
In the midst of an energy crisis and coal shortage in the severe winter cold, the population watched the Czechoslovak hockey team's two triumphs over the Soviets at the world cup on March 21 and 28 in Stockholm, triggering an eruption of joyous demonstrations. The score of 2:0 and a week later of $4: 3$ gave an unexpected impulse to national patriotic sentiment and anti-Soviet expressions on the streets. They also provoked the dark forces of the regime into instigating an action that might have been behind the vandalizing of the Soviet airline office of Aeroflot in the center of Prague. This time, the Dubček leadership fully identified itself with the Soviet critics and, in doing so, broadened the gulf between his leadership and the population, whom he had courted for a year. Soon after on March 31 and without Dubček's knowledge, Marshal Andrei Grecko, the Soviet minister of defense landed in Czechoslovakia and demanded that censorship be installed and that the Czechoslovak military forces repress the 'counterrevolution.' If not, Grecko threatened, the Soviet army would do the job. Dubček understood that his head was on the line. ${ }^{36}$

The day after the game, on March 29, "I received a phone call from a man who introduced himself as Šíma," Vladimír jotted down afterwards. "In a composed and courteous manner, he blamed me for the agitation of the previous night. He added that all of us in the mass media are to be blamed because we were sowing hate, hysteria and above all fascism among the people." 37 The voice on the other side of the telephone line continued: the presence of Soviet forces on Czechoslovak soil was justified, the media's activities during the past August were illegal and the entrance of the army was correct. After some attempt to debate with Šima, which did not go anywhere, Vladimír sat at his typewriter and wrote down his

36 Dubček, Alexander and Jiři Hochman (1993), Naděje umirá posledni. Vlastni životopis. Praha: Svoboda, pp. 23741; Williams, Kieran (1997). The Prague Spring and its Aftermath. Czechoslovak politics 1968-1970, Cambridge, Cambridge University Press, pp. 193-198; Tigrid, Pavel (1971), Why Dubček Fell. London: Macdonald, pp. 155-167.

37 VT, 'Může za to Dzurilla,' typescript, pa. Dzurilla was the hockey team's gatekeeper. thoughts in an ironic feuilleton about the hockey team gatekeeper's responsibility for the lineup's triumph and the popular reaction which so infuriated the authorities.

However, the centerpiece of his reflection was socialism: on the one hand, there was dogmatic socialism, "based on the hard bureaucratic-police apparatus both in the party and in all the other institutions; with its permanent suspicion of deviations, of flirting with the class enemy, of espionage and treason"; and on the other hand, there was "socialism with a human face, democratic, humanistic socialism."38

In the spirit of Marxism, albeit simplified, Vladimír conceded that everything including institutions, opinions and ideas evolved, but failed to recognize the basic historical premise that the past lived in the present; a past that would soon haunt him.

\section{April}

After the daily Práce published Vladimír's article on March 1 in full, the newspaper asked interior minister Josef Grösser for a comment. There was no reply until April 11. When it arrived, it was a tape recording, provided by the interior ministry's head of the office for issuing passports and visas in which, "without providing concrete arguments he intimated that there had been some sort of relations in the past between the author of the article and Security [organs]." The newspaper called Vladimír for a comment but did not find him. The ministry's reply also indicated that it granted Vladimír his passport and the exit permit. ${ }^{39}$

The recorded voice belonged to Colonel doctor Zdeněk Rajchart, the office chief himself. A man of intelligence and cunning, Rajchart was probably selected for the task to perform a role equal to a seasoned publicist. If Vladimír asked for explanations about the interrogation that he had been subjected to the previous month, Rajchart was there to provide it thanks to a careful study of that interrogation which the ministry recorded

38 VT, typescript, no title, no date, pa.

39 Rajchart, Zdeněk (1969), 'Vážený soudruhu redaktore, Práce, April 12, 4. 
without Vladimír's knowledge. Vladimír had not crossed the border at a designated crossing point on August 26, 1968, charged the taped voice that was transcribed in a long newspaper article. It was true that Vladimír had the right documents, but on crossing the frontier to Austria, his papers were not stamped. By then Rajchart knew who helped Vladimír to cross the border. Allegedly, when Soviet tanks were approaching the hill from which the team was transmitting the layout of the troops and the social and political atmosphere it created, the border officer offered Vladimír and his television team a shelter on the Czechoslovak side of the border, but "Tosek was so anxious and fearful, and for that reason insisted on an immediate departure abroad." However, by then Rajchart's central point was not whether the transmission was legal or illegal or why Vladimír crossed the border the way he did; what mattered most was that Tosek spoke arrogantly to his interrogators from the moral high ground and criticized their daring to treat him as if he were a delinquent. ${ }^{40}$ Rajchart had a trump card hidden up his sleeve. In a well calculated move, he showed his hand: "But you know, don't you that you did not always have such a negative attitude to Security [organs] as you assume now?." Could it have been the case that Vladimír's attitude then was an attempt to atone for his sins from the past, Rajchart concluded: "Now that the whole affair has been clarified, you will be given the exit permit." 41

Nothing was cleared up during the interrogation and no more information was obtained than what the secret police already knew, but getting information was not the point; most likely, Rajchart was put in charge of the case because he had valuable material with which to discredit Vladimír, smearing his past, and thus questioning the reform process of 1968 which the journalist and his cohort stood for.

Before Vladimír left Prague, he wrote a rebuttal to Rajchart's article. Indeed, nume-

40 lbid.

41 See also 'Kdo koho ostrihal?' Rudé právo, Prague, (April 12, 1969), 2. rous readers of Práce requested further explanations which the newspaper asked him to supply. Vladimír objected to Rajchart's slight that he was afraid when Soviet tanks were reported as drawing nearer the transmitter and "even more illustrative were the intimations repeated several times made by Colonel dr. Rajchart about my 'alleged relations with his ministry."' In his defense, Vladimir pointed out that during the fifties he was accused of collaboration with British, American and other foreign organs, and recently was smeared on the pages of Zprávy. But Rajchart chose well where it hurt most. The ministry issued Vladimír his passport and the exit permit, clearing the ministry's reputation before the public, while at the same time it created an air of suspicion around Vladimír as an honest journalist with consequences for his reputation at home and abroad.

The reference to his collaboration with the interior ministry's secret service was as low as it could get. Vladimír was concerned about the effect such a 'recommendation' might have on his colleagues and readers at home and abroad. Before leaving Prague, he thanked the many citizens who sent him or conveyed personal manifestations of support, trust and encouragement. ${ }^{42}$

Vladimír sent his reply to Práce and Rudé právo. ${ }^{43}$ Práce set the article in print but could not publish it due to government instructions to all newspaper offices on April 15 that it was not desirable to discuss Tosek's case any further. ${ }^{44}$ Vladimír's rebuttal was published on April 30 in Filmové a televizní noviny, which did not heed the instructions. Vladimir denied any connection with the interior ministry, which he knew was damning and disqualifying in the public eyes. By the time the article came out, he was back in Vienna. He left Prague on April 24 by train. As if they had been warned beforehand, the custom officers at the border searched his luggage inside out. ${ }^{45}$

\footnotetext{
42 'Závěrečné vyjádření V. Toska,' typescript, pa.

43 The organs of the labor unions and the communist party respectively.

44 'VT redakci Rudého práva,' Prague, April 15, 1969; Josef Vávra to VT, April 15, 1969, pa.

$45 \mathrm{VT}$, 'Kterak jsem si šel pro vlnu a vrátil se ostřihán,' Film-
} 
By then, the pieces that completed the 'normalization' process were all in place. To the relief of his opponents, Dubček resigned as the Czechoslovak Communist Party secretary apparently on his own free will and gave his blessing to Husák as his replacement, thus fulfilling the president's promise to Marshal Andrei Grecko. By resigning, in order to contribute to the alleged struggle against the anti-socialist and rightist opportunist forces, and to strengthen party unity and to build better relations with the USSR, Dubček accepted Soviet pressures lock, stock and barrel. ${ }^{46}$ Throughout the months that followed the foreign occupation, Dubček used his moral capital to gradually lower the population's expectations, trade off some aims on the promise of future rewards and persuade the majority to demobilize. In the belief that they were salvaging the reform course, Dubček and others who resisted the Soviet demands to dismantle that process facilitated the restoration of authoritarian rule by providing powerful incentives for public self-restraint in demanding an end to the foreign occupation. Dubček's understanding of political reality was that the country would settle down, foreign troops would leave, and reforms continue, but for this to happen the public had to comply and continue to back the leadership.

Many journalists complied with the request for self-censorship on condition that the party leaders produce substantial results and that the measures be temporary. Dubček's abdication in April was the culmination of the defeatist policy of the Prague Spring leadership, generating a sense of frustration in the population and facilitating 'normalization.' Dubček, unwittingly, wounded the reform in an effort to save it. ${ }^{47}$

ové a televizní noviny, 3 (April 30, 1969), 6; VT, 'Zpráva o prohlídce zavazadel $V$. Toska príslušníky pohraniční stráze Ministerstva vnitra,' typescript, pa.

46 Williams, Kieran (1997), The Prague Spring and its Aftermath. Czechoslovak politics 1968-1970, Cambridge: Cambridge University Press, pp. 206-208.

47 Prečan, Vilém (1993), 'Lid, veřejnost, občanská společnost jako aktér Pražského jara 1968,' in Pecka, Jindřich and Vilém Prečan, Proměny Pražského jara 1968-1969. Sborník studii a dokumentü o nekapitulantských postojich $v$ československé společnosti, Brno: Doplněk, pp. 13-36; Williams, Kieran (1997). The Prague Spring and its Aftermath.
There were no purges, jailing, or persecution of law-abiding citizens who opposed the 'normalization' until Husák became the party's secretary. The press had been relatively free; no scientist or journalist had to wash windows to earn a living, the cultural scene was lively and travel abroad was permitted until December 1969. With Husák at the helm of the party, the 'normalization' process was thorough. Journalists were dismissed and replaced by lackeys of the system; journals were shut down and jailing of oppositionists returned to become a practice or a threat. The atmosphere of the repressive fifties was restored, though without the hanging. But according to Dubček, April 1969 was the final act of treason of the Prague Spring. ${ }^{48}$ At the time, he did not fathom his own contribution for it to happen.

\section{The State Secret Security Files}

So, what did Rajchart have in mind in his cryptic allusion to Vladimír's collaboration with the secret police? And why reopening the case is relevant for the analysis of Tosek's trajectory?

On May 25, 1958, Jiří Čermák, an employee of the state secret security, reported to his superior: "I have carried out a personal acquaintance with comrade Tosek Vladimír, Prague television journalist. I met Tosek through another television journalist, who is our informant, and was introduced as the informant's friend." Čermák was impressed by Vladimír's intelligence and the love of his family. Tosek seemed to be the type of a person who fulfilled "our requirements to become a collaborator." His recruitment would not be a problem, because he was "rationally and I think emotionally on our side." 49 His tasks as an agent were to work in the area of 'westerners,' but also to re-

Czechoslovak politics 1968-1970, Cambridge: Cambridge University Press, pp.45-58; 144-148.

48 Williams, Kieran (1997). The Prague Spring and its Aftermath. Czechoslovak politics 1968-1970, Cambridge: Cambridge University Press, (226-243); Dubček, Alexander and Jiři Hochman (1993), Naděje umirá poslední. Vlastni životopis, Praha: Svoboda, pp.221-224; Wilson, Paul (1993), 'Unlikely Hero,' New York Review of Books, September 23. 49 Čermák, Jiři. 'Záznam o osobním poznáni,' Prague, May 25, 1958, ABS, file 43891-020-0029. 
port on people who worked in the foreign section of Czechoslovak radio and on foreigners arriving in Czechoslovakia. Given his relations abroad, he was to be used as a liaison person during his travels. He could be trusted and would be recruited "on the strength of his ideology," his belonging to the party and "devotion to the popular democratic regime." Since Vladimír was compromised by his previous personal contacts with people liquidated during the Slánský trial in 1952, with people who escaped from Czechoslovakia after the Communist takeover in February 1948, including his sister, and by having served in the western army during the war, it was believed that Vladimír would be a loyal collaborator. When Čermák interviewed him, Tosek "understood correctly the state security political tasks and committed himself to working with us." He promised to communicate information he gleaned from contacts with foreigners and was ready to reestablish written contacts with people he knew from his war-time emigration. ${ }^{50}$

Before the actual recruitment took place, several people who knew Vladimír were consulted as to his character and political standing. In his favor was the fact that during the Hungarian uprising of 1956 "he stood uncompromisingly against the counterrevolution," 51 a euphemism used to denounce the revolt against the communist regime in Hungary.

Vladimír was recruited in February 1959. He met with Čermák in a wine cellar in the center of Prague at 1 o'clock in the afternoon; the restaurant was almost empty, so they could talk undisturbed. Vladimír confided in the handler about his family, his first wife's infidelity and his reluctance to grant her a divorce, for which she was asking because of the four children they had together. He offered an immediate collaboration: "a new opportunity to make himself useful

50 Npor. Emil Kovar, 'Předkládám návrh na verbovku, Prague, December 12, 1958, ABS, file 43891-020-0031. Rudolf Slánský and other high-ranking communists had been falsely accused of espionage, sabotage and treason, and in fabricated trials condemned to death by hanging in 1952.

51 'Petr,' 'Tosek-Tausig, Vladimír-poznatky,' Prague, 6.18.1958, ABS, 43891-020-0027. Broadly speaking, the Hungarian October of 1956 was a forerunner of the Prague Spring of 1968. to us propped up at the world hockey cup where he will act as a translator for western foreign journalists and hence will be in dayto-day contact with them." Tosek was interested in teamwork with the security organs, and given his character and linguistic skills, "here is a total guarantee of a good collaborator." His cover name was to be Cornel. ${ }^{52}$

However, in early November 1959, Vladimír was asked to report on the political and ideological profile of female announcers on Czechoslovak television and his colleagues. In an interview with one of them in November 2017, Kamila Moučková, the former news presenter abounded in glowing compliments about Vladimír and the entire television team which she joined in 1957. She might have never learnt about Vladimír's report, it might have had no impact on her career in the Czechoslovak television, or if she knew, she might have forgotten it. ${ }^{53}$

Vladimír described Moučková as someone who came from a Communist family, but whose political profile was questionable: "in her attitude to life and work she lacks communist spirit. She is a typical petty bourgeois lady, too much interested in money and trying to work as little as possible - and for that in different engagements to earn as much as possible - and at times she conceals her hypocritical feelings with hysterical outbursts even during party meetings at which she tries to simulate her abundant awareness. She deceives some people, not all." About another anchor person he had little to say, and in order to say anything he relied on another person's information. One announcer, he reported, was politically uneducated and only interested in her looks, while the third one, one of the best, recently divorced, was politically passive. Of the fourth one he knew nothing, wrote Vladimír, alias Jiři Váňa. ${ }^{54}$

However, denigrating other person's life and character worked in both directions. In

\footnotetext{
52 'Záznam o verbovce,' Prague, 2.26.1959, ABS, file 43891020-0034.

53 Author's interview with Kamila Moučková, Prague, November 13, 2017.

54 'Jiří Váňa,' 'Jako hlasatelky v Cs. Televizi v Praze ucinkuji,' 11.27.1959, Pracovní svazek, no. 43 891/020, Prague, ABS, 43891-020-0053-55.
} 
May 1960 Josef reported on Vladimír that he was an extremely intelligent man, with many languages under his belt and knowledge of the world, "but he is a typical cosmopolitan, who cares only about his prosperous livelihood." 55

Travels abroad to western countries were a coveted prize in the 1960s. In the light of what the interior ministry expected of its agent, it encouraged Vladimír's trips, hoping he would bring back useful 'defensive' information. Before each journey, he was briefed on whom to approach on the understanding that the world out there was a dangerous place, that people from communist countries had to be on the lookout for provocation by 'reactionary elements' and then accused of provoking violence and debriefed on his return.

In October 1960, Vladimír participated in an International Student Union conference in Iraq. He duly reported on the political behavior of both Iraqis and Czechs and excused himself for not being able to deliver more because he fell ill. Still, the disputes among the delegates from one country or another, China or Japan, Arabs or Palestinians and the ideological leanings of one or another were useful, serving the ministry as barometers of international tensions. One point of dispute was the inevitability of a third world war, which some delegates propagated, and others denied. ${ }^{56}$

From Iraq Vladimír travelled to a world meeting of journalists in Austria. Without citing anyone, he mentioned that somebody in Prague wanted to obstruct his participation by denying him a visa. Did someone want to participate in his stead or was it due to any animosity towards Vladimír? At the meeting, the adherents to the Soviet bloc and pro-Chinese journalists were at loggerheads over the correct interpretation of what constituted a communist movement. Unlike the Chinese communists who

\footnotetext{
55 'Josef,' 'Tosek Vladimír z Cs. Televize-poznatky,' Prague, 5.30.1960. ABS, file 43891-020-0091. In communist parlance, cosmopolitan was a derogatory epithet used primarily for Jews.

56 'Pramen se zúčastnil od 5. do 16. řijna 1960 zájezdu pořádaného Mezinárodním svazem studentstva do Iraku na VI. kongres MSS.' ABS, file 43891-020-0063-75.
}

had fallen into isolation, he stated that Latin American journalists acted together with the Czechoslovaks even without belonging to any communist party. ${ }^{57}$ These might have been incisive observations, but the handlers hoped for more substantial information.

Doubts existed about Vladimír's usefulness for domestic intelligence, although from time to time he was requested to report on individuals at home but not much was expected. As a party member "he is not trusted by people with enemy intentions and cannot be given tasks related to them." One official, Mayor Zezula, suggested that Vladimír be used only for tasks while abroad. ${ }^{58}$

In March 1961, Vladimír was sent to Casablanca in Morocco to interpret at a meeting of the International Student Union leadership. His report consisted of political analysis of the struggle among different leftist groups vying for power in their countries, which it was his job to translate from one language to another. As reports from previous trips, his analysis added to the understanding of the international tug of ideological war among the participants, divided into progressive, reactionary and revisionists like the Yugoslavs; he provided names, nationalities, and organizations to which they belonged. A lover of foreign travels, Vladimír used the occasion to shoot scenes from Moroccan life and with no money to spare he hitchhiked to get to the places he wanted to get on film. ${ }^{59}$

Vladimír was asked periodically to report on people he had met in England during the war or to write reports on his television colleagues, their character and political views, which went hand in hand. In doing so, he had to be on the lookout for who was connected to whom, when and how as a friend, as a husband or as a lover; where, with whom and in what material conditions they lived. ${ }^{60}$

\section{Ibid.}

58 Mayor Jan Zezula, Prague, February 10, 1961. ABS, file 43891-020-0081.

59 'Jiří Váňa,' 'Od 14. do 31. III. 1961 konal se zájezd skupiny pracovníků sekretariátu MSS a externích spolu pracovníků společně s predstaviteli některých členských organizaci MSS do Maroka.' Prague, ABS, file 43891-020-0083-91. 60 'Jiři Váňa,' 'Karel Veselý,' Prague, August 11, 1961. ABS, file 43891-020-0107 
Vladimír's disposition to collaborate with the state's secret service went on without blemish. There was no need to dangle any perks before him or blackmail him into cooperation as happened with so many unsuspecting informers. Cornel proved trustworthy, capable and reliable, but his usefulness was limited for both intelligence and counterintelligence. He did not go out of his way to seek information on other individuals. While abroad he met many, but always related to his work as an interviewer or a documentarist, and always with other people close by. When in 1965 he was requested to report on a television employee whose sister married an American citizen, he delivered next to nothing because the woman in question was uninterested in having any contact with Vladimír. "The collaborator acted correctly, is interested in cooperation and fulfills tasks with which he is entrusted well." 61 By 1966, information regarding agent Corne/ petered out in the interior ministry archive.

So, what of it? If it had not been for Rajchart's revelation of Tosek's collaboration with the secret police, we would not have found out and our understanding of Vladimír's role as a leading journalist on the Czechoslovak television during the communist era would have missed important elements. His cooperation with the security organs, which oversaw and kept under control the entire political system, explains his uncritical reporting during the 1960 s all the way till 1968 when the system cracked from within and the reform movement was initiated. No longer beholden to the old regime, Tosek participated in building socialism with a human face, as the movement was called. Once aborted, Tosek's world collapsed. There was no return to the old system, then 'normalized', so emigration was the only option.

\section{Final reflections}

In a letter to his colleague Ladislav Daneš in July 1969, Vladimír wrote: "I insist that I belong to this no matter how proscribed com-

61 'Vyhodnocení spol. Cornela,' Prague, February 15, 1965 ABS, file 43891-020-0128. pany -after having been blind for so long that I gobbled it up and defended it completely, with errors and crimes- so I, who am aware of it all, I belong to it, and they are the usurpers. So, any 'measures' and 'steps' will be their responsibility." 62 Vladimír meant that his belonging to the Czechoslovak Communist Party was permanent, even if the party might expel him from its ranks. ${ }^{63}$

Vladimír was sacked from the Czechoslovak television, his permit to stay abroad expired, he was expelled from the party and stripped of his citizenship. The employment in the Italian television proved an illusion because of internal organizational conflicts. Even though he was paid a salary, no concrete assignment ever materialized. After a year in Rome and an intense search for an alternative occupation, Vladimír landed a job at the $B B C$ radio monitoring service in England. It was not an ideal job for a seasoned television journalist, but it paid the bills. Furthermore, by listening to the news from Eastern Europe, day in day out, he kept abreast of events in the home terrain. However, Vladimír had withdrawn from active political engagement, for nothing could replace communication in Czech with readers and listeners at home. Even in the land of free speech, Czechoslovak 'normalization' managed to silence him. Not until he found his voice and venue in the exile journal of the socialist opposition Listy did he publish anything and even there he wrote randomly and most of the time under a pseudonym. ${ }^{64}$ The fact that he left three children in Czechoslovakia also played a role in his keeping a low profile. ${ }^{65}$ We shall never know what effect the revelation of his association with the state secret police had on his intellectual and emotional disposition in emigration.

Vladimír Tosek was one of the builders of the authoritarian system in Czechoslovakia, albeit a minor cog in a big machine. By joining the reform movement in 1968, he sought

\footnotetext{
62 VT to Ladislav Daneš, Rome, July 17, 1969, pa.

63 Hochman, Jiři (1974), 'Očista Svazu českých novinářủ. Listy, 5-6, December, pp. 37-39.

64 Havliček, Dušan (2008), Listy v exilu, Olomouc, Burian a Tichák.

65 His second son Jan joined him in emigration in Septem-
} ber 1969 
to correct the system's vices which, as we now know, not only could not be corrected, but whose iniquities continued throughout the 'normalization' era all the way to 1989. In 1969, Tosek negotiated his legal status with a government and a party, closely supervised by the occupiers, which punished him brutally for daring to defy the system during the spring and summer of 1968. It reminded him of his past, which the unrepentant Vladimír might have wished to remain covered by archival dust.

\section{References}

Bren, Paulina (2010), The Greengrocer and his TV: The Culture of Communism after 1968 Prague Spring, Ithaca and London, Cornell University Press.

Čermák, Jiří (1958), 'Záznam o osobním poznání,' Prague, May 25, ABS, file 43891-020-0029.

Cysařová, Jarmila (1993), Česká televizni publicistika, svědectví šedesátých let, Prague, Edice Česke televize 66.

Cysařová, Jarmila (2003), 'V Československé televizi,' Jiři Pelikán 1923-1999, Sborník. OPS občanský dialog, Prague.

Daneš, Ladislav (2005), Můj život s múzami, televizí a tak vưbec, Prague, Malá Skála.

Doskočil, Zdeněk (2006), Duben 1969. Anatomie jednoho mocenského zvratu, Brno, Doplněk.

Dubček, Alexander and Jiři Hochman (1993), Naděje umirá poslední. Vlastní životopis, Prague, Svoboda.

Havliček, Dušan (2008), Listy v exilu, Olomouc, Burian a Tichák.

Hochman, Jiří (1974), 'Očista Svazu českych novinářu,' Listy, 5-6, December.

Hochman, Jiři (1988), 'Words and Tanks: The Revival, the Struggle, the Agony and Defeat (1968-1969)', in Pehe, Jiři ed., The Prague Spring: A Mixed Legacy, New York, Freedom House.
'Jiři Váňa,' 'Jako hlasatelky v Cs. Televizi v Praze ucinkuji' (1959), Pracovní svazek, no. 43 891/020, 11.27.1959, Prague, ABS, 43891020-0053-55.

'Jiři Váňa' (1961), 'Od 14. do 31. III. 1961 konal se zájezd skupiny pracovníků sekretariátu MSS a externích spolu pracovníků společně s představiteli některých členských organizaci MSS do Maroka,' Prague, ABS, file 43891020-0083-91.

'Jiří Váňa,' 'Karel Veselý' (1961), Prague, August 11, ABS, file 43891-020-0107.

'Josef,' 'Tosek Vladimír z Cs. Televize-poznatky' (1960), Prague, 5.30.1960. ABS, file 43891020-0091.

Kavan, Jan (1988), 'From the Prague Spring to the Long Winter,' in Pehe, Jiři ed., The Prague Spring: A Mixed Legacy, New York, Freedom House.

Klíma, Ivan. My Crazy Century. New York, Grove Press, 2013.

Kosta, Jiří. Život mezi úzkostí a nadějí. Prague, Paseka, 2002.

Kusín, Vladimir. From Dubček to Charter 77: A Study of Normalization in Czechoslovakia, 1968-1978. New York, St. Martin's Press, 1978.

Otáhal, Milan. 'K některým otázkám dějin "normalizace"', Soudobé dějiny 1 (1995).

Pecka, Jindřich and Vilém Prečan, Proměny Pražského jara 1968-1969. Sbornik studii a dokumentů o nekapitulantských postojich $\checkmark$ československé společnosti. Brno, Doplněk, 1993.

Pehe, Jiři ed. The Prague Spring: A Mixed Legacy. New York, Freedom House, 1988.

Petráš, Jiří and Libor Svoboda eds. Jaro' 68 a nástup normalizace. Československo v letech 1968-1971. České Budějovice and Praha, Ústav pro studium totalitních režimů, 2017.

Prečan, Vilém 'Lid, veřejnost, občanská společnost jako aktér Pražského jara 1968,' 
in Precan, Promeny Prazskeho jara 19681969. Sbornik studii a dokumentu o nekapitulantskych postojich $v$ ceskoslovenske spolecnosti, Doplnek, Brno, 1993.

Pulec, Martin. 'Nestandardní jevy u Pohraniční stráže v posrpnovém období roku 1968,' Úrad dokumentace a vyšetřování zločinů komunismu, 2013.

Rajchart, Zdeněk. 'Vážený soudruhu redaktore,' Práce, (12 April 1969)

Raška, Francis D. The Long Road to Victory: A History of Czechoslovak Exile Organizations. New York, East European Monograhs, 2012.

Rychlík, Jan. 'Překračování hranic a emigrace v Československu a východní Evropě ve 20. století,' Securitas imperii, 29 (2016).

Šimečka, Milan. Obnovení pořádku. Koln: Index, 1979.

Šimečka, Milan. 'Strategie naděje,' Listy (13 March 1969).

Štoll, Martin. Television and Totalitarianism in Czechoslovakia. From the First Democratic Republic to the Fall of Communism. New York: Bloomsbury, 2019.

Švejkovský, Jiří. Čas marných naději. Roky 1968 a 1969 ve zpravodajství ČST. Prague: Epocha, 2010.

Sviták, Ivan. The Czechoslovak Experiment 19681969. New York and London, Colombia University Press, 1971

Tigrid, Pavel. Why Dubček Fell. London, Macdonald, 1971.

Tosek, Vladimír. 'Moje únorové události,' Reportér, IV/8 (27 February 1969).

Tosek, Vladimír. 'Kterak jsem si šel pro vlnu a vrátil se ostřihán,' Práce, (1 March 1969).

Tosek, Vladimír. 'Kterak jsem si šel pro vlnu a vrátil se ostřihán,' Filmove a televizni noviny, 3 (30 April 1969).
Váňa, Josef. 'Z televizní kuchyňe a zákulisí,' Zprávy, 15 March (1969).

Vinen, Richard. The Long '68. Radical Protest and Its Enemies. London, Penguin Random House, 2019.

Williams, Kieran. The Prague Spring and its Aftermath. Czechoslovak politics 1968-1970. Cambridge, Cambridge University Press, 1997.

Wilson, Paul. 'Unlikely Hero,' New York Review of Books, (23 September 1993).

Recibido: 11 de diciembre de 2020. Reenviado: 7 de enero de 2021. Aceptado: 8 de febrero de 2021.

\section{Daniela Spenser}

Daniela Spenser nació en Checoslovaquia. Emigró a Gran Bretaña en 1968 después de la ocupación soviética. Estudió literatura española y latinoamericana en King's College, Universidad de Londres y antropología en London School of Economics and Political Science. Llegó a México en 1972. Después de trabajar como antropóloga en Chiapas, Spenser estudió la maestría en la Facultad en Ciencias Políticas y Sociales de la UNAM y el doctorado en historia en la Universidad de Carolina del Norte en Chapel Hill. Ha sido profesora e investigadora en el Centro de Investigaciones y Estudios Superiores en Antropología Social en la Ciudad de México desde 1980. Es miembro del Sistema Nacional de Investigadores, nivel III. Su más reciente libro es En combate: la vida de Lombardo Toledano (México, Penguin Random House, 2018; en inglés: In Combat: The Life of Lombardo Toledano, Leiden, Brill, 2019; Chicago, Haymarket, 2020). Este artículo forma parte del libro en preparación, provisionalmente titulado Fragmented Times, Divided Lives: The Itineraries of a European Family. 